\title{
PENGARUH AIR HUJAN TERHADAP KARAKTERISTIK MARSHALL CAMPURAN ASPAL PANAS PADA LAPIS PERMUKAAN JALAN
}

\author{
Ida Bagus Wirahaji ${ }^{1}$ dan AAA Made Cahaya Wardani ${ }^{2}$ \\ 1,2 Program Studi Teknik Sipil FT Unhi \\ ib.wirahaji@gmail.com; agungmadecahaya@yahoo.com
}

\begin{abstract}
ABSTRAK
Lapis permukaan perkerasan jalan umumnya berupa AC-WC, merupakan konstruksi yang berada di alam terbuka dan berinteraksi langsung dengan cuaca dan suhu yang berubah-ubah. Pada musim hujan, permukaan jalan terus menerus diguyur air bahkan terkena genangan air. Kondisi ini sangat melemahkan struktur AC-WC, karena air dapat memisahkan ikatan aspal dengan agregat. Tujuan penelitian ini untuk mengetahui pengaruh lamanya waktu perendaman terhadap Karakteristik Marshall Campuran AC-WC dengan menggunakan dua sampel agregat Ex. Sebudi dan agregat Ex. Seririt.

Penelitian ini dilakukan di Laboratorium Penyedia Jasa di Desa Sebudi Karangasem. Pertama-tama dilakukan pemeriksaan nilai properties masingmasing fraksi agregat dari kedua sampel agregat. Kemudian membuat benda uji untuk perendaman $1 \times 24,2 \times 24,3 \times 24$, dan $4 \times 24$ jam, masing-masing 3 buah benda uji. Kemudian dilakukan pemeriksaan persentase rongga terhadap benda uji tersebut, untuk memperoleh nilai VMA, VFB, dan VIM. Terakhir dilakukan pengujian dengan alat uji Marshall untuk mendapatkan nilai stabilitas, kelelehan (flow) dan Marshall Quotient (MQ).

Hasil penelitian menunjukkan nilai properties agregat Ex. Sebudi lebih buruk dari agregat Ex. Seririt. Nilai VMA dan VIM semakin meningkat, sedangkan nilai VFB semakin menurun untuk kedua jenis campuran dengan bertambahnya lama waktu perendaman. Nilai stabilitas dan Marshall Quotient (MQ) semakin menurun, sedangkan kelelehan semakin meningkat dengan bertambahnya lama waktu perendaman. Nilai kelelehan AC-WC Ex. Sebudi mencapai 4,39 mm, AC-WC Ex. Seririt 4,47 mm pada perendaman 4x24 jam, melampui batas maksimum interval 2-4 mm. Nilai MQ AC-WC Ex. Sebudi 196,99 kg.mm, AC-WC Ex. Seririt 215,56 kg/mm, dibawah batas minimal 250 $\mathrm{kg} / \mathrm{mm}$ pada perendaman $4 \times 24$ jam. AC-WC Ex. Sebudi lebih cepat mengalami penyimpangan terhadap persyaratan Spesifikasi Umum 2010 Revisi 3.
\end{abstract}

Kata kunci: Perendaman, AC-WC, dan Karakteristik Marshall. 


\section{PENDAHULUAN \\ Latar Belakang}

Konstruksi perkerasan jalan merupakan konstruksi yang pada umumnya berada di alam terbuka, baik di perkotaan maupun di pedesaan. Kecuali, pada tempat-tempat tertentu, seperti di dalam terowongan atau di bawah permukaan tanah. Konstruksi perkerasan jalan terus menerus menerima cuaca dan suhu yang berubahubah. Pada siang hari saat matahari terik konstruksi perkerasan menerima suhu panas yang tertinggi, kemudian malam menerima suhu dingin.

Saat terjadi hujan, air hujan mengguyur dan membasahi permukaan jalan. Apabila permukaan jalan itu adalah konstruksi Laston, maka lapis asphalt concrete wearing course (ACWC)-lah yang tertimpa air hujan. Untuk menghindari tergenangnya air hujan, AC-WC diberi kemiringan 2\% agar air hujan mengalir ke saluran samping (Sukirman, 1999). Namun demikian, seringkali terjadi genangan air hujan pada lapis permukaan jalan akibat tidak berfungsinya saluran samping, yang disebabkan tidak adanya pemeliharaan rutin saluran samping dan juga rendahnya kesadaran penduduk dalam membuang sampah rumah tangga.

Selain itu, durasi hujan yang cukup lama, sekalipun airnya dapat mengalir terus, dapat dipandang sebagai air genangan, karena terus menerus membasahi permukaan jalan. Lapis permukaan jalan berada dalam kondisi basah dalam waktu yang lama. Kondisi ini sangat berpengaruh pada umur pelayanan jalan. Kinerja aspal sebagai bahan pengikat akan terganggu oleh campur tangan air yang masuk ke dalam campuran AC-WC. Gejala-gejala yang sering terjadi di lapangan adalah berupa pelepasan butir, terbentuk lubang-lubang setempat-setempat, dan kemungkinan yang paling buruk adalah air dapat meresap ke lapisan di bawah AC-WC (Sukirman, 1995).

Penelitian-penelitian mengenai pengaruh air hujan terhadap perkerasan jalan telah dilakukan para peneliti. Arifin (2008), meneliti pengaruh air hujan terhadap nilai karakteistik Marshall Campuran Lapisan Aspal Beton. Secara keseluruhan nilai karakteristik Marshall mengalami penurunan seiring dengan bertambahnya kandungan air hujan. Nurhudayah dkk (2009), meneliti tentang pengaruh genangan air terhadap kerusakan jalan di Kota Gorontalo. Hasil penelitiannya menyimpulkan bahwa kerusakan jalan Kota Gorontalo selain karena masa pelayanan jalan yang telah lewat juga disebabkan oleh genangan dan gerusan air. Bentuk-bentuk kerusakan antara lain: berlubang, retak-retak, terlepasnya lapis permukaan dan kerusakan tepi perkerasan jalan. Dando (2016) menganalisis pengaruh perendaman air hujan terhadap kinerja campuran aspal berongga berbasis asbuton butir. Penelitian ini bertujuan untuk mengetahui karakteristik Marshall dan sifa-sifat agregat dari campuran aspal berongga asbuton butirSemakin lama direndam dengan air hujan maka nilai IKS sampuran aspal menjadi semakin menurun atau campuran semakin tidak baik.

Ketiga penelitian di atas, tidak menyebut Ex. Material agregat yang digunakan dalam penelitian. Seperti diketahui, sumber material sangat berpengaruh terhadap kinerja ruas jalan. Masing-masing lokasi sumber material agregat memiliki properties tersendiri terhadap agregatnya. Pada penelitian ini digunakan sumber material Ex. Sebudi Karangasem dan sumber material Ex. 
Seririt Buleleng. Material agregat Ex. Sebudi Karangasem dipilih karena persediaan materialnya paling banyak digunakan dalam konstruksi jalan, sedangkan material agregat Ex. Seririt Buleleng dipilih karena termasuk lokasi penambangan galian $\mathrm{C}$ terbaru.

\section{Rumusan Masalah}

Dari latar belakang di atas, maka dapat ditarik rumusan masalah penelitian sebagai berikut:

1. Bagaimanakah perbandingan nilai kadar rongga dalam campuran ACWC yang terendam air pada material agregat Ex. Sebudi Karangasem dan material agregat Ex. Seririt Buleleng?

2. Bagaimanakah perbandingan nilai Marshall dalam campuran AC-WC yang terendam air pada material agregat Ex. Sebudi Karangasem dan material agregat Ex. Seririt Buleleng?

\section{Tujuan Penelitian}

Tujuan dari penelitian ini adalah sebagai berikut:

1. Untuk mengetahui perbandingan nilai kadar rongga dalam campuran AC-WC yang terendam air pada material agregat Ex. Sebudi Karangasem dan material agregat Ex. Seririt Buleleng.

2. Untuk mengetahui perbandingan nilai Marshall dalam campuran ACWC yang terendam air pada material agregat Ex. Sebudi Karangasem dan material agregat Ex. Seririt Buleleng.

\section{Batasan Penelitian}

Adapun batasan dalam penelitian ini adalah sebagai berikut:

1. Penelitian ini dilakukan pada skala laboratorium.
2. Lapis Permukaan yang dijadikan objek penelitian adalah Laston ACWC.

3. Aspal pengikat yang digunakan adalah aspal penetrasi $60 / 70$ Pertamina.

4. Agregat yang digunakan bersumber dari mesin pemecah batu PT. Sari Amerta Gina Utama dan PT. Adi Murti.

5. Rendaman yang digunakan adalah air tawar. Pada penelitian ini air hujan digunakan untuk zat cair sebagai perendam diasumsikan menggantikan air tawar.

6. Variasi lama perendaman yang dilakukan adalah $2 \times 24$ jam, 3×24 jam, dan 4x24 jam.

7. Job Mix Formula (JMF) yang digunakan adalah Paket Proyek Pemeliharaan Rekontruksi Jalan Nasional Tahun Anggaran 2016.

\section{METODE PENELITIAN}

Prosedur Penelitian

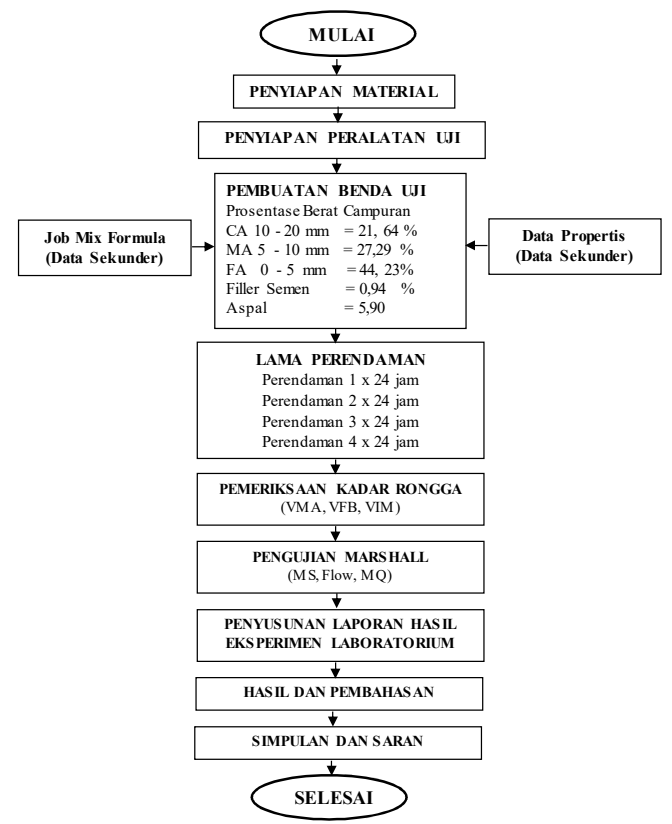

Gambar 2.1 Diagram Penelitian 
Penyiapan Material Penyusun Campuran AC-WC

Penyiapan material penyusun campuran AC-WC dilakukan mengumpul-kan material tersebut di Laboratorium. Material penyusun yang dimaksud adalah:

1. Agregat.

Agregat diambil dari lokasi mesin pemecah batu (stone Crusher) yang terletak di base camp PT Adi Murti di dusun Badeg, desa Sebudi, kecamatan Selat, Karangasem dan PT. Sari Amerta Gina Utama di desa Seririt Buleleng. Agregat yang kumpulkan di Laboratorium adalah:

1) Agregat Kasar (CA 1-2 cm)

2) Agregat Sedang (MA $1 / 2-1 \mathrm{~cm}$ )

3) Agregat Halus (FA $0-1 / 2 \mathrm{~cm}$ )

2. Semen sebagai bahan pengisi (filler).

Dipakai portland cement (PC) tipe I dalam percobaan ini dipakai semen Gersik.

3. Aspal penetrasi $60 / 70$.

Aspal penetrasi 60/70 merupakan aspal keras yang umum digunakan pada proyek jalan di Bali, baik jalan nasional, provinsi, maupun kabupaten. Cairan aspal diperoleh dari AMP PT. Adi Murti

\section{Pembuatan Benda Uji}

Pembuatan benda uji dilakukan dengan membuat campuran AC-WC sesuai dengan proporsi data sekunder yang tertera dalam JMF AC-WC paket Proyek Pemeliharaan Paket Pemeliharaan Rekonstruksi Jalan Nasional Batas Kota Amlapura-SerayaCulik-Subagan-Embuh. Kadar aspal yang dipakai sebesar 5,9\%. JMF ini digunakan dalam penelitian ini karena merupakan proporsi yang sering digunakan dalam berbagai proyek jalan, yang sesuai dengan percobaanpercobaan di Laboratorium Aspal PT. Adi Murti di Base Camp dusun Badeg, Desa Sebudi, Kecamatan Selat, Karangasem

Adapun proporsi dalam campuran agregat dan proporsi dalam campuran aspal, seperti Tabel 3.1.

Tabel 3.1 Proporsi Material Penyusun AC-WC

\begin{tabular}{|c|l|c|c|}
\hline o. & $\begin{array}{c}\text { Material } \\
\text { Penyusun } \\
\text { AC-WC }\end{array}$ & $\begin{array}{c}\text { Prosentase } \\
\text { Total } \\
\text { Berat } \\
\text { Agregat } \\
(\%)\end{array}$ & $\begin{array}{c}\text { Prosentase } \\
\text { Total Berat } \\
\text { Campuran } \\
(\%)\end{array}$ \\
\hline & CA $1-2 \mathrm{~cm}$ & 23 & 21,64 \\
\hline & MA $1 / 2-1 \mathrm{~cm}$ & 29 & 27,29 \\
\hline & FA 0-1/2 cm & 47 & 44,23 \\
\hline & Filler Semen & 1 & 0,94 \\
\hline & Aspal & - & 5,90 \\
\hline & 100 & 100,00 \\
\hline
\end{tabular}

Sumber: SKPJN Wilayah II (2016)

Benda uji dibuat 2 (dua) jenis, yaitu yang menggunakan material agregat Ex, Sebudi Karangasem dan material agregat Ex. Seririt Buleleng. Masing-masing jenis dibuat 9 (sembilan) benda uji, dengan 3 (tiga) benda uji untuk masing-masing variasi perendaman. Variasi lama perendaman direncanakan 1x24jam, 2x24 jam, 3x24 jam, dan 4x24 jam. Pembuatan benda uji sejumlah 21 (dua puluh satu) buah mengikuti prosedur sesuai SNI 06-24891991.

\section{HASIL DAN PEMBAHASAN Prosentase Rongga}

Tabel 4.1 dan Gambar 4.1 menunjukkan nilai VMA dari masingmasing campuran AC-WC yang berasal dari agregat Ex. Sebudi dan Ex. Seririt. Dalam Tabel 4.1 terlihat bahwa, kedua campuran baik campuran AC-WC dari 
agregat Ex. Sebudi dan Ex. Seririt menunjukkan kecenderungan meningkatnya nilai VMA dengan semakin bertambahnya lamanya durasi perendaman.

Semakin besar nilai VMA dari suatu campuran AC-WC semakin kecil nilai stabilitasnya. Campuran dengan VMA yang besar mengakibatkan problem stabilitas dan menjadikan campuran tidak ekonomis untuk diproduksi.

Tabel 4.1 Lama perendaman dan nilai VMA

\begin{tabular}{|c|c|c|c|c|}
\hline \multirow[b]{2}{*}{ No. } & \multirow{2}{*}{$\begin{array}{c}\text { Lama } \\
\text { Perendaman }\end{array}$} & \multicolumn{2}{|c|}{ Nilai VMA (\%) } & \multirow[b]{2}{*}{ Spec } \\
\hline & & $\begin{array}{c}\text { Ex. } \\
\text { Sebudi }\end{array}$ & $\begin{array}{c}\text { Ex. } \\
\text { Seririt }\end{array}$ & \\
\hline 1. & $\begin{array}{l}\text { Selama } 1 \quad x \\
24 \text { jam }\end{array}$ & 15,55 & 15,21 & \multirow{4}{*}{$\begin{array}{l}\text { Min } \\
15 \%\end{array}$} \\
\hline 2. & $\begin{array}{l}\text { Selama } 2 x \\
24 \text { jam }\end{array}$ & 15,73 & 15,27 & \\
\hline 3. & $\begin{array}{l}\text { Selama } 3 x \\
24 \text { jam }\end{array}$ & 16,53 & 15,53 & \\
\hline 4. & $\begin{array}{l}\text { Selama } 4 \quad x \\
24 \text { jam }\end{array}$ & 17,18 & 16,09 & \\
\hline
\end{tabular}

Sumber: Hasil Analisis (2018).

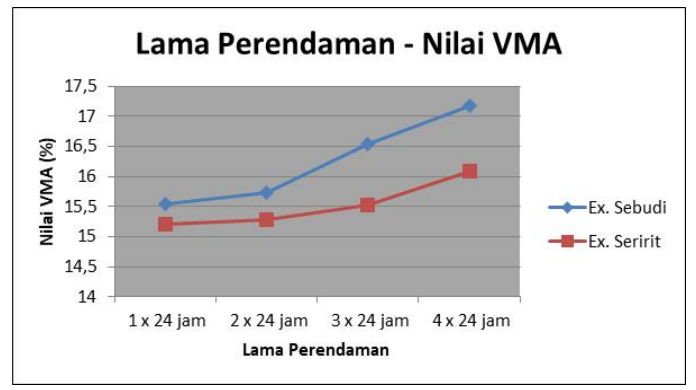

Gambar 4.1 Hubungan Lama

Perendaman - Nilai VMA

Sumber: Hasil Analisis (2018).

Tabel 4.2 dan Gambar 4.2 menunjukkan hubungan lamanya perendaman terhadap nilai VFB. Baik campuran AC-WC dari agregat Ex. Sebudi maupuan dari agregat Ex. Seririt menunjukkan kecenderungan menurun dengan semakin lamanya durasi perendaman. Dalam Tabel 4.2 terlihat bahwa untuk durasi lama perencaman $2 \times 24$ jam pada campuran AC-WC dari agregat Ex.. Sebudi sudah menunjukkan penyimpangan terhadap spesifikasi, yaitu sebesar 64,11\% kurang dari persyaratan minimal $65 \%$. Sedangkan, pada campuran AC-WC dari agregat Ex. Seririt menunjukkan penyimpangan terhadap persyaratan spesifikasi pada durasi lama perendaman 4x24 jam, yaitu $63,54 \%$ kurang dari spesifkasi min $65 \%$.

Tabel 4.2 Lama perendaman dan nilai VFB

\begin{tabular}{|c|c|c|c|c|}
\hline \multirow[b]{2}{*}{ No. } & \multirow{2}{*}{$\begin{array}{c}\text { Lama } \\
\text { Perendaman }\end{array}$} & \multicolumn{2}{|c|}{ Nilai VFB (\%) } & \multirow[b]{2}{*}{ Spec } \\
\hline & & $\begin{array}{c}\text { Ex. } \\
\text { Sebudi }\end{array}$ & $\begin{array}{c}\text { Ex. } \\
\text { Seririt }\end{array}$ & \\
\hline 1. & $\begin{array}{lll}\text { Selama } & 1 & x \\
24 \text { jam } & & \\
\end{array}$ & 65,08 & 67,91 & \multirow{4}{*}{$\begin{array}{l}\text { Min } \\
65 \%\end{array}$} \\
\hline 2. & $\begin{array}{l}\text { Selama } 2 x \\
24 \text { jam }\end{array}$ & 64,11 & 67,60 & \\
\hline 3. & $\begin{array}{l}\text { Selama } 3 x \\
24 \text { jam }\end{array}$ & 60,24 & 66,29 & \\
\hline 4. & $\begin{array}{l}\text { Selama } 4 \quad x \\
24 \text { jam }\end{array}$ & 55,72 & 63,54 & \\
\hline
\end{tabular}

Sumber: Hasil Analisis (2018).

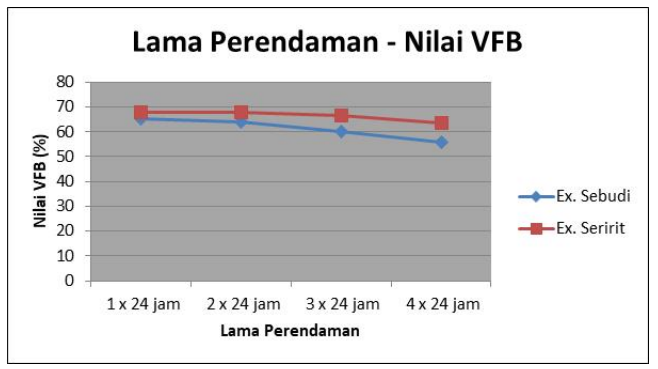

Gambar 4.2 Hubungan Perendaman Nilai VFB

Sumber: Hasil Analisis (2018)

Semakin lama durasi perendaman semakin renggang jarak antar butir-butir agregat, sehingga VMA makin besar. VMA yang makin besar dengan kadar aspal yang tetap menyebabkan nilai VFB semakin menurun. Nilai VFB yang kecil 
berpengaruh terhadap kekedapan campuran terhadap air dan udara, karena lapis film aspal akan menjadi tipis dan akan mudah retak bila menerima beban sehingga campuran aspal mudah teroksidasi yang akhirnya menyebabkan lapis perkerasan memiliki umur layanan yang pendek.

Tabel 4.3 dan Gambar 4.3 menunjukkan hubungan pengaruh lamanya perendaman terhadap nilai VIM campuran AC-WC yaitu campuran AC-WC dari agregat Ex. Sebudi dan agregat Ex. Seririt. Kecenderungan yang ditunjukkan oleh Tabel 4,3 dan Gambar 4.3 adalah, semakin lama waktu perendaman semakin besar nilai VIM campuran.

Pada durasi perendaman $1 \times 24$ jam, nilai VIM AC-WC dari agregat Ex. Sebudi sebesar $4.08 \%$ dan AC-WC dari agregat Ex. Seririt sebesar 4,38, kedua jenis campuran masih memenuhi rentang spesifikasi, yaitu 3-5\%. Pada perendaman 2x24 jam, nilai VIM ACWC dari agregat Ex. Sebudi sebesar $5,29 \%$ sudah tidak memenuhi spesifikasi, dan nilai VIM AC-WC dari agregat Ex. Seririt sebesar 4,95\% masih memenuhi spesifikasi. Semakin besar pori yang tersisa semakin tidak kedap air dan semakin banyak udara di dalam campuran, yang menyebabkan semakin mudahnya selimut aspal beroksidasi dengan udara dan menjadi getas, durabilitas menurun.

Tabel 4.3 Lama perendaman dan nilai VIM

\begin{tabular}{|c|c|c|c|c|}
\hline \multirow[b]{2}{*}{ No. } & \multirow[b]{2}{*}{$\begin{array}{c}\text { Lama } \\
\text { Perendaman }\end{array}$} & \multicolumn{2}{|c|}{ Nilai VIM (\%) } & \multirow[b]{2}{*}{ Spec } \\
\hline & & $\begin{array}{c}\text { Ex. } \\
\text { Sebudi }\end{array}$ & $\begin{array}{l}\text { Ex. } \\
\text { Seririt }\end{array}$ & \\
\hline 1. & $\begin{array}{lll}\text { Selama } & 1 & x \\
24 \text { jam } & & \\
\end{array}$ & 4,08 & 4,38 & \\
\hline 2. & $\begin{array}{lll}\text { Selama } & 2 & x \\
24 \text { jam } & & \\
\end{array}$ & 5,29 & 4,95 & $\begin{array}{c}3- \\
5 \%\end{array}$ \\
\hline 3. & $\begin{array}{lll}\text { Selama } & 3 & x\end{array}$ & 6,18 & 5,23 & \\
\hline
\end{tabular}

\begin{tabular}{|c|lll|l|l|l|}
\hline & 24 jam & & & & \multirow{2}{*}{} \\
\hline 4. & $\begin{array}{l}\text { Selama } \\
24 \text { jam }\end{array}$ & 4 & $\mathrm{x}$ & 7,34 & 5,87 & \\
\hline
\end{tabular}

Sumber: Hasil Analisis (2018).

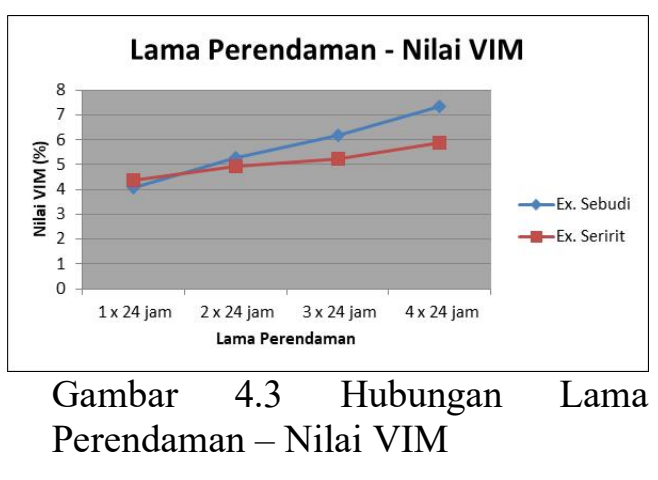

Nilai VIM berfungsi untuk membatasi kadar aspal dalam campuran AC-WC. VIM berpengaruh terhadap keawetan lapis perkerasan, semakin tinggi nilai VIM menunjukan semakin besar rongga dalam campuran sehingga campuran bersifat porous. Dengan nilai VIM yang tinggi menyebabkan campuran kurang kedap, udara dan air dapat masuk lebih banyak. Sedangkan, lapis AC-WC sebagai lapis permukaan (surface course) jenis Laston yang bersifat struktural, disyaratkan harus kedap air untuk mencegah air masuk meresap kedalam lapisan di bawahnya, yaitu AC-BC atau bahkan AC-Base.

\section{Nilai Marshall}

Tabel 4.4 dan Gambar 4.4 menunjukkan hubungan lamanya perendaman terhadap nilai stabilitas dari masing-masing campuran AC-WC. Kecenderungan yang ditunjukkan pada Tabel 4.4 dan Gambar 4.4 adalah semakin lama durasi perendaman semakin turun nilai stabilitas. Dalam penelitian ini nilai stabilitas masih memenuhi syarat, yaitu untuk campuran AC-WC dari agregat Ex. Sebudi mencapai stabilitas sebesar $864,1 \mathrm{~kg}$ dan 
campuran AC-WC dari agregat Ex. Seririt mencapai nilai stabilitas $963,6 \mathrm{~kg}$ pada perendaman selama $4 \times 24$ jam. Penurunan stabilitas ini terjadi akibat pengaruh air yang meresap ke dalam campuran, melemahkan ikatan antara aspal dan agregat

Tabel 4.4 Lama perendaman dan MS

\begin{tabular}{|c|c|c|c|c|}
\hline \multirow{2}{*}{ No. } & \multirow{2}{*}{$\begin{array}{c}\text { Lama } \\
\text { Perendaman }\end{array}$} & \multicolumn{2}{|c|}{$\begin{array}{c}\text { Marshall } \\
\text { Stability (kg) }\end{array}$} & \multirow{2}{*}{ Spec } \\
\hline & & $\begin{array}{c}\text { Ex. } \\
\text { Sebudi }\end{array}$ & $\begin{array}{c}\text { Ex. } \\
\text { Seririt }\end{array}$ & \\
\hline 1. & $\begin{array}{lll}\text { Selama } & 1 & x \\
24 \text { jam } & & \\
\end{array}$ & $1.171,2$ & $1.365,5$ & \multirow{4}{*}{$\begin{array}{c}\text { Min } \\
800 \\
\mathrm{~kg}\end{array}$} \\
\hline 2. & $\begin{array}{lll}\text { Selama } & 2 & x \\
24 \text { jam } & & \\
\end{array}$ & $1.155,7$ & $1.291,0$ & \\
\hline 3. & $\begin{array}{lll}\text { Selama } & 3 & x \\
24 \text { jam } & & \\
\end{array}$ & 975,5 & $1.067,9$ & \\
\hline 4. & $\begin{array}{l}\text { Selama } 4 \quad x \\
24 \text { jam }\end{array}$ & 864,1 & 963,6 & \\
\hline
\end{tabular}

Sumber: Hasil Analisis (2018).

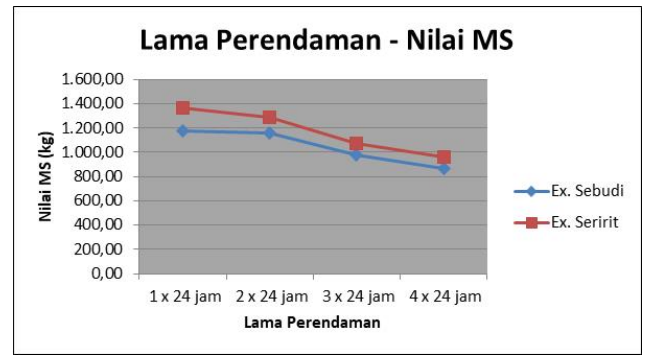

Gambar 4.4 Hubungan Lama Perendaman - Marshall Stability

Sumber: Hasil Analisis (2018)

Dari Tabel 4.4 dan Gambar 4.4 terlihat nilai stabilitas campuran ACWC dari agregat Ex. Sebudi selalu lebih rendah dari pada nilai stabilitas campuran AC-WC dari agregat Ex. Seririt. Hal ini sesuai dengan nilai berat jenis agregat, di mana berat jenis agregat Ex. Sebudi lebih kecil daripada berat jenis Ex. Seririt. Berat jenis. Berat jenis agregat, terutama agregat kasar (CA) dan sedang (MA) memberi kontribusi pada nilai stabilitas suatu campuran beton aspal.
Tabel 4.5 dan Gambar 4.5 menunjukkan hubungan pengaruh lamanya durasi perendaman terhadap nilai kelelehan plastis. Kecenderungan yang ditunjukkan adalah semakin lama durasi perendaman semakin besar nilai kelelehannya. Spesifikasi Umum 2010 Revisi 3 memberi persyaratan nilai kelelehan dalam interval 2-4 mm. Sasil pengujian Marshall menujukkan bahwa pada durasi perendaman 4x24 jam nilai kelelehan dari kedua jenis campuran AC-WC telah melampui persyaratan maksimum spesifikasi. Nilai kelelehan campuran AC-WC dari agregta Ex. Sebudi sebesar 4,39 $\mathrm{mm}$ dan campuran AC-WC dari agregat Ex. Seririt sebesar $4,47 \mathrm{~mm}$, melampui batas maksimum $4,00 \mathrm{~mm}$.

Tabel 4.5 Lama perendaman dan nilai

\begin{tabular}{|c|c|c|c|c|}
\hline \multirow[b]{3}{*}{ No. } & \multicolumn{3}{|c|}{ Flow } & \multirow[b]{3}{*}{ Spec } \\
\hline & \multirow{2}{*}{$\begin{array}{c}\text { Lama } \\
\text { Perendaman }\end{array}$} & \multicolumn{2}{|c|}{ Nilai Flow (mm) } & \\
\hline & & $\begin{array}{c}\text { Ex. } \\
\text { Sebudi }\end{array}$ & $\begin{array}{c}\text { Ex. } \\
\text { Seririt }\end{array}$ & \\
\hline 1. & $\begin{array}{lll}\text { Selama } & 1 & x \\
24 \text { jam } & & \end{array}$ & 2,37 & 3,28 & \multirow{4}{*}{$\begin{array}{l}2-4 \\
\mathrm{~mm}\end{array}$} \\
\hline 2. & $\begin{array}{l}\text { Selama } 2 x \\
24 \text { jam }\end{array}$ & 2,48 & 3,32 & \\
\hline 3. & $\begin{array}{l}\text { Selama } 3 \quad x \\
24 \text { jam }\end{array}$ & 3,86 & 3,99 & \\
\hline 4. & $\begin{array}{lll}\text { Selama } & 4 & x \\
24 \text { jam } & & \\
\end{array}$ & 4,39 & 4,47 & \\
\hline
\end{tabular}

Sumber: Hasil Analisis (2018)

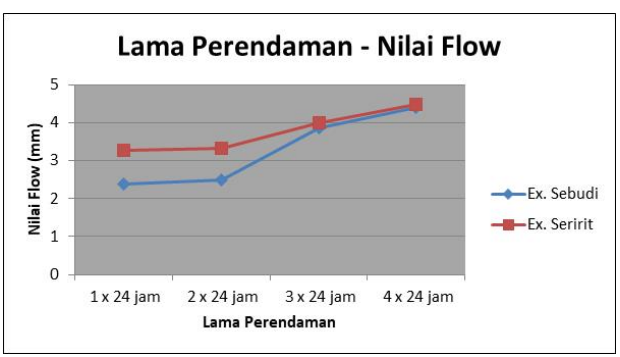

Gambar 4.5 Hubungan lama

Perendaman - Flow

Sumber: Hasil Analisis (2018) 
Tabel 4.6 dan Gambar 4.6 menunjukkan hubungan lamanya durasi perendaman terhadap nilai Marshall Quotient (MQ). Hubungan yang ditunjukkan adalah semakin lama durasi perendaman semakin kecil nilai MQ. Hal ini disebabkan oleh semakin mengecilnya nilai stabilitas dan semakin besarnya nilai kelelehan sebagai faktor pembagi.

Tabel 4.6 Lama perendaman dan nilai

\begin{tabular}{|c|c|c|c|c|}
\hline \multirow[b]{3}{*}{$\begin{array}{c}\text { No } \\
\cdot\end{array}$} & \multicolumn{4}{|c|}{ Flow } \\
\hline & \multirow{2}{*}{$\begin{array}{c}\text { Lama } \\
\text { Perendam } \\
\text { an }\end{array}$} & \multicolumn{2}{|c|}{$\begin{array}{c}\text { Nilai MQ } \\
(\mathrm{kg} / \mathrm{mm})\end{array}$} & \multirow[b]{2}{*}{ Spec } \\
\hline & & $\begin{array}{c}\text { Ex. } \\
\text { Sebu } \\
\text { di }\end{array}$ & $\begin{array}{c}\text { Ex. } \\
\text { Serir } \\
\text { it }\end{array}$ & \\
\hline 1. & $\begin{array}{l}\text { Selama } 1 \mathrm{x} \\
24 \text { jam }\end{array}$ & $\begin{array}{c}494,8 \\
6\end{array}$ & $\begin{array}{c}415,8 \\
8\end{array}$ & \multirow{4}{*}{$\begin{array}{c}\text { Min } \\
250 \\
\mathrm{~kg} / \mathrm{m} \\
\mathrm{m}\end{array}$} \\
\hline 2. & $\begin{array}{l}\text { Selama } 2 \times \\
24 \text { jam }\end{array}$ & $\begin{array}{c}399,3 \\
7\end{array}$ & $\begin{array}{c}389,2 \\
4\end{array}$ & \\
\hline 3. & $\begin{array}{l}\text { Selama } 3 \times \\
24 \text { jam }\end{array}$ & $\begin{array}{c}252,7 \\
3\end{array}$ & $\begin{array}{c}267,4 \\
1\end{array}$ & \\
\hline 4. & $\begin{array}{l}\text { Selama } 4 x \\
24 \text { jam }\end{array}$ & $\begin{array}{c}196,9 \\
9\end{array}$ & $\begin{array}{c}215,5 \\
6\end{array}$ & \\
\hline
\end{tabular}

Sumber: Hasil Analisis (2018).

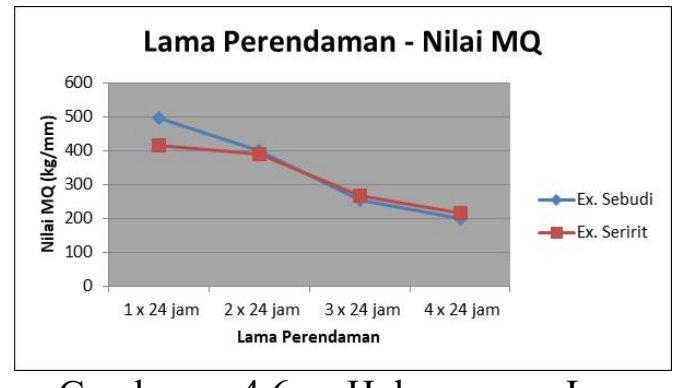

Gambar 4.6 Hubungan Lama

Perendaman - Marshall Quotient

Sumber: Hasil Analisis (2018)

Perendaman dengan lama waktu $1 \times 24$ jam sampai dengan $3 \times 24$ jam memberikan hasil MQ pada campuran AC-WC yang masih memenuhi spesifikasi. Pada durasi perendaman
$4 \times 24$ jam campuran AC-WC dari agregat Ex. Sebudi nilai MQ yang mencapai sebesar 196,99 kg/mm, sedangkan campuran AC-WC dari agregat Ex. Seririt mencapai sebesar $215,56 \mathrm{~kg} / \mathrm{mm}$. Kedua nilai MQ tersebut berada di bawah persyaratan nilai MQ minimum $250 \mathrm{~kg} / \mathrm{mm}$. Dengan demikian, pada perendaman 4x24 jam, campuran AC-WC sangat rentan mengalami deformasi plastis.

\section{PENUTUP}

\section{Simpulan}

Dari analisis dan pembahsan pada bab sebelumnya, maka dapat disimpulkan beberapa hal sebagai berikut:

1. Nilai VMA dari kedua jenis campuran semakin membesar dengan bertambahnya lama waktu perendaman. Nilai VMA yang makin jauh terhadap nilai minimal $15 \%$ menyebabkan campuran ACWC memiliki satbilitas makin kecil.

2. Nilai VFB dari kedua jenis campuran semakin menurun dengan bertambahnya lama waktu perendaman. Nilai VFB campuran AC-WC agregat Ex. Sebudi pada perendaman 2x24 jam mencapai $64,11 \%$, sedangkan campuran ACWC Ex. Seririt pada perendaman 4x24 jam mencapai 63,54\%, tidak memenuhi persyaratan minimal $65 \%$.

3. Nilai VIM dari kedua jenis campuran semakin meningkat dengan bertambahnya lama waktu perendaman. Nilai VIM campuran AC-WC agregat Ex. Sebudi pada perendaman 2x24 jam mencapai $5,29 \%$ sedangkan campuran ACWC Ex. Seririt pada perendaman $3 \times 24$ jam mencapai 5,23\%, melebih batas maksimal interval 3-5\%. 
4. Campuran AC-WC Ex. Sebudi lebih cepat mengalami penyimpangan terhadap persyaratan VIM dan VFB daripada campuran AC-WC Ex. Seririt.

5. Nilai Stabilitas dari kedua jenis campuran semakin menurun dengan bertambahnya lama waktu perendaman, tetapi sampai perendaman $4 \times 24$ jam, kedua jenis campuran masih memenuhi persyaratan minimal stabilitas 800 $\mathrm{kg}$.

6. Nilai Kelelehan dari kedua jenis campuran semakin meningkat dengan bertambahnya lama waktu perendaman. Kedua jenis campuran melampui batas maksimal interval 2-4 mm pada perendaman $4 \times 24$ jam.

7. Nilai Marshall Quotient (MQ) dari kedua jenis campuran semakin menurun dengan bertambahnya lama waktu perendaman. Kedua jenis campuran memiliki nilai Marshall Quotient di bawah persyaratan minimal $250 \mathrm{~kg} / \mathrm{mm}$ pada perendaman $4 \times 24$ jam.

\section{Saran}

Dari simpulan di atas, maka dapat diberikan saran-saran sebagai berikut:

1. Quarry Desa Sebudi kecamatan Selat Kabupaten Karangasem memiliki deposit material yang banyak, tetapi memiliki nilai properties yang kurang. Untuk itu yang perlu dilakukan adalah upayaupaya untuk men-treatment agregat tersebut sehinggan memenuhi spesifikasi.

2. Untuk menjaga agar permukaan AC-WC selalu kedap air, sebaiknya dtambahkan bahan aditif anti stripping agent, untuk mencegah masuknya air ke dalam pori-pori campuran AC-WC, sehingga kerusakan-kerusakan seperti pengelupasan, pelepasan butir dan lain sebagainya dapat dicegah lebih dini dan umur layanan dapat dipertahankan.

3. Penelitian ini hanya menggunakan 2 (dua) sampel material yang berbeda, penelitian berikutnya dapat dikembangkan dengan lebih dari dua meterial pada quarry yang berbeda dan tersebar di Bali Barat, Utara, dan Timur.

\section{DAFTAR PUSTAKA}

Arifin, M.Z, dkk. 2008. Pengaruh Kandungan Air Hujan Terhadap Nilai Karakteristik Marshall Campuran Lapisan Aspal Beton (Laston). Jurnal Rekayasa Sipil, Volume 2 No. 1. Malang: Jurusan Sipil Fakultas Teknik, Universitas Brawijaya.

Asiyanto. 2008. Metode Konstruksi Proyek Jalan. Jakarta: Universitas Indonesia (UI-Press)

Core Team Bina Marga Bali. 2014. Laporan Kunjungan AMP dan Evaluasi Job mix Formula 2014. Denpasar: Satuan Kerja Perencanaan dan Pengawasan Jalan Nasional Provinsi Bali.

Dando, Alfred N M, dkk. 2016. Analisis Pengaruh Perendaman Air Hujan Terhadap Kinerja Campuran Aspal Berongga Berbasis Asbuton Butir. Tugas Akhir. Makassar: Jurusan Sipil Fakultas Teknik Universitas Hasanuddin.

Direktorat Jenderal Bina Marga (Dirjen BM). 1987. Standar Konstruksi Bangunan Indonesia (SKBI) 1987 tentang Petunjuk 
Pelaksanaan Lapis Aspal Beton (LASTON) Untuk Jalan Raya. Jakarta: Departemen Pekerjaan Umum.

Direktorat Jenderal Bina Marga (Dirjen BM). 2014. Spesifikasi Umum 2010 Revisi 3. Jakarta: Kementerian Pekerjaan Umum.

Hardiyatmo, H.C. 2011. Perancangan Perkerasan Jalan dan Penyelidikan Tanah. Yogyakarta: Jurusan teknik Sipil dan Lingkungan, Fakultas Teknik, Universitas Gajah Mada

Nurhudayah, dkk. (2009). Studi Genangan Air Terhadap
Kerusakan Jalan di Kota Gorontalo. Simposium XII FSTPT Universitas Kristen Petra Surabaya, 14 November 2009. Surabaya: Universitas Kristen Petra Surabaya.

Satuan Kerja Pelaksanaan Jalan Nasional (SKPJN) Wilayah II Provinsi Bali. 2016. Job Mix Formula $A C-W C$. Denpasar: Diraktorat Jenderal Bina Marga.

Sukirman, S. 1995. Perkerasan Lentur Jalan Raya. Jakarta: Granit

Sukirman, S. 1999. Dasar-dasar Perencanaan Geometrik Jalan. Cetakan ke-tiga. Bandung: Nova. 